\title{
Clinical Assessment of Amyloid Imaging in Alzheimer's Disease: A Systematic Review of the Literature
}

\author{
Philip Wahlster Charlotte Niederländer Christine Kriza Sandra Schaller \\ Peter L. Kolominsky-Rabas \\ Interdisciplinary Center for Health Technology Assessment and Public Health, University of \\ Erlangen-Nuremberg, National Cluster of Excellence 'Medical Technologies - Medical Valley \\ EMN', Erlangen, Germany
}

\section{Key Words}

Alzheimer's disease - Amyloid imaging - Clinical assessment of Alzheimer's disease ·

Diagnosis of Alzheimer's disease - Systematic literature review

\begin{abstract}
Background/Aims: Healthcare systems face an increased prevalence of Alzheimer's disease and increasing costs. The use of molecular biomarkers and imaging could offer an effective solution for these issues. The objective of this study was to assess amyloid imaging regarding clinical utility and impact. Methods: A literature search was performed in several databases, searching articles between 2008 and January 2013 following the Preferred Reporting Items for Systematic Reviews and Meta-Analyses (PRISMA) guidelines. The results are reported according to the clinical correlates of amyloid imaging. Results: Thirty-three studies were included in the final analysis. Five studies evaluated amyloid imaging for diagnosis. Nine studies assessed the prognostic value. Twenty-two studies provided correlations to cognitive measures. Amyloid imaging provides a high reliability in diagnosis and prognosis, but cognitive measures only showed weak correlations. Conclusion: The evidence clearly indicated that amyloid imaging has not arrived yet in clinical practice. However, it can provide substantial benefits in special aspects of diagnostic accuracy and for a diagnosis up to 10 years before clinical diagnosis. This can be a base for early preventive treatment strategies such as antiamyloid therapy. In this context, amyloid imaging is crucial to understand the early pathologic process in Alzheimer's disease.


Wahlster et al.: Clinical Assessment of Amyloid Imaging in Alzheimer's Disease: A Systematic Review of the Literature

\section{Introduction}

Among all mental disorders, dementia had the highest costs per person in 2010 [1]. Costeffective drugs like donepezil can preserve dementia patients' independence and thus reduce costs for informal care [2]. The use of molecular biomarkers in oncology for a better stratification of patients encourages hopes for the field of psychiatry. Genetic testing can be used to select dementia patients for donepezil treatment in a cost-effective manner [3]. Molecular imaging is one of the most promising technologies to visualize molecular physiologic actions in real time. The pharmaceutical industry is already regularly using these methods to determine the dose-effect relationship of new drugs and to identify patient subgroups [4]. As molecular diagnostics has the potential to speed up diagnosis and treatment, it can also reduce the length of hospital stay [5] and finally the costs of dementia.

The diagnosis of Alzheimer's disease (AD) is currently based on clinical symptoms and signs of cognitive decline in multiple domains. However, it is challenging to distinguish other kinds of dementia and the pathologic features of AD regarding the transitional state of mild cognitive impairment (MCI) before AD develops [6]. In terms of molecular imaging, the hypothesis that $\mathrm{AD}$ is caused by amyloid deposition at a very early stage is accepted by many researchers, but has yet to be definitely proven. The fundamental limitation of amyloid imaging is that amyloid is a required aspect for diagnosing AD, however it is not sufficient as a sole factor for diagnosis. One reason is the lack of specificity for $\mathrm{AD}$, as it is found in a significant proportion of healthy older people as well as in other non-AD dementias [7]. Therefore, the U.S. National Institute on Aging - Alzheimer's Association (NIA-AA) workgroups on diagnostic guidelines recommend using amyloid imaging in asymptomatic individuals only for research purposes. It is not appropriate to perform amyloid imaging in the absence of objective evidence of cognitive impairment [8].

A systematic review is important given the recent approval of amyloid positron emission tomography (PET) by the European Medicines Agency (EMA) and the Food and Drug Administration (FDA) for clinical use and the active debate about the clinical utility of this technology [9].

A review of the latest literature referring to amyloid imaging in dementia is expected to provide a comprehensive summary and overview of the available evidence relating to amyloid imaging with the most studied tracer, Pittsburgh Compound B ([C-11]PiB) [10]. The objective of this review was to assess the clinical benefit of amyloid imaging via [C-11]PiBPET in MCI and AD patients. Clinical benefits were defined as cognitive correlates, contributions to diagnosis and prediction of conversion.

\section{Methodology}

Search Strategy and Study Selection

The objective and the search strategy were established using the Population, Intervention, Comparator, Outcome (PICO) scheme [11]. The following databases were searched: Medline, PubMed, Scopus, Cochrane Library, PsycINFO, psychiatry online journals and the individual journals Lancet, Health Affairs, Personalized Medicine and Pharmacoeconomics. The search was performed for articles published between January 2008 and January 2013 in English and German. Since the technical feasibility of amyloid imaging is improving rapidly, we only considered studies published within the last 5 years [12,13]. PICO-specific search terms regarding the population ('Alzheimer's disease', 'Alzheimer dementia', 'mild cognitive impairment', 'MCI') were combined with keywords concerning the examined intervention ('Pittsburgh compound B', 'PiB', 'positron emission tomography', 'PET', 'amyloid imaging'). The search terms used were the result of testing different search strategies. Finally, after performing the search, citation snowballing was used to make sure that all relevant literature was found. The review process followed the Preferred Reporting Items for Systematic Reviews and Meta-Analyses (PRISMA) guidelines [14]. 
Wahlster et al:: Clinical Assessment of Amyloid Imaging in Alzheimer's Disease:

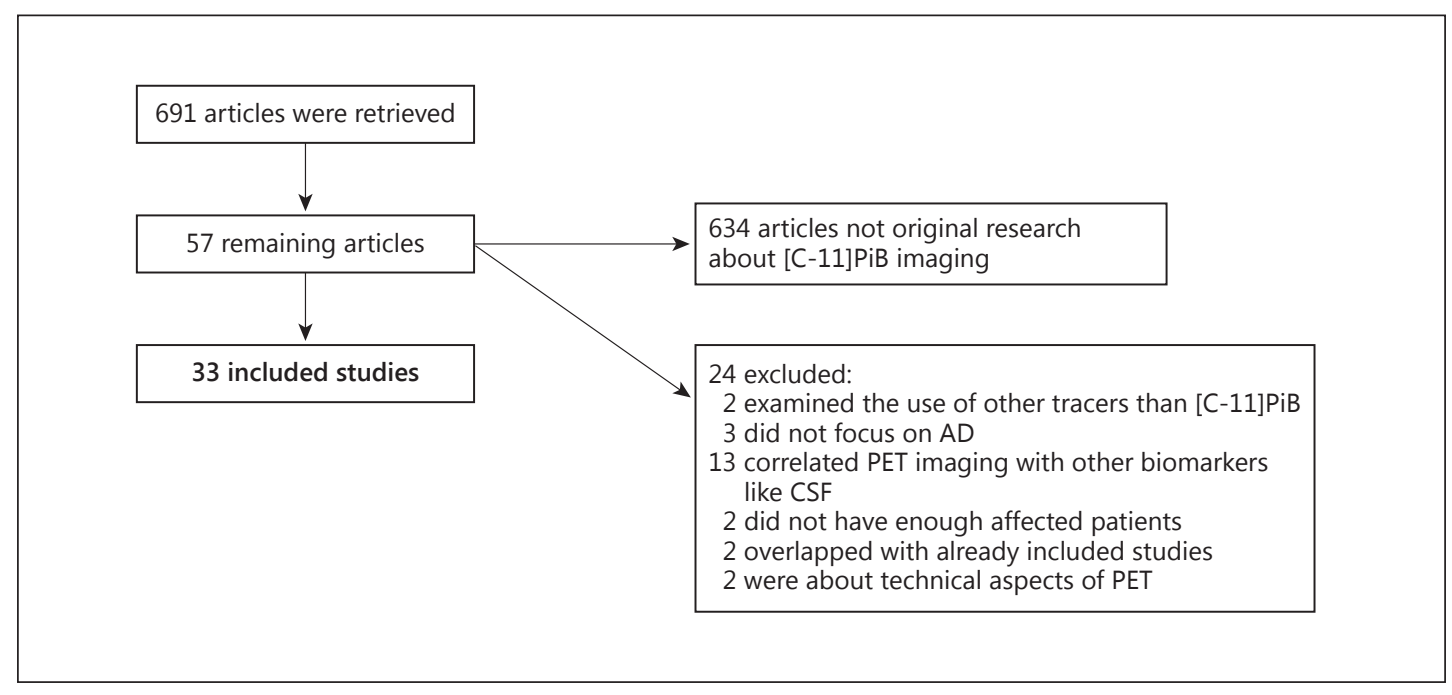

Fig. 1. Schematic representation of how the papers were selected.

\section{Inclusion/Exclusion Criteria}

Eligible studies were required to assess at least diagnostic accuracy. Diagnostic accuracy is defined by clinical measures which 'attempt to measure performance of the imaging for the purpose of making diagnoses' [15]. Clinical studies with less than $10 \mathrm{MCI}$ or AD patients or studies comparing amyloid imaging to other biomarkers were excluded. Studies had to be published as peer-reviewed journal articles. The title and abstract of all retrieved articles were reviewed by the first author (P.W.). The full texts of articles that met the inclusion criteria were reviewed more closely in conjunction with a medical expert (P.L.K.R.) who has a clinical background in neurology and psychiatry. The quality of research papers was evaluated according to adequacy of description of the theoretical framework, background and methodology. We used a modified version of the QUADAS items [16].

\section{Data Extraction}

A data extraction form was tested using a sample of studies before initiating full data extraction. Data collected from individual papers included author, year of publication, reference test, study population and main results regarding amyloid imaging.

Reporting of Results and Synthesis

Results of amyloid imaging studies were reported by sorting the information into different groups of clinical applications. The results are reported according to the clinical correlates of amyloid imaging.

\section{Results}

\section{Search Results}

Within the search, 3,226 papers were retrieved and 2,535 were excluded for not being focused on amyloid imaging, including duplicates. 691 papers were retrieved and 634 were excluded for not being original research on amyloid imaging in AD. Again the selection was refined accordingly. From this cohort, papers were selected for the literature synthesis. The reasons for exclusions are outlined in figure 1 . We also included 3 studies with elderly subjects who were assessed with normal cognition, but with a follow-up to diagnosis of AD [17-19]. In 2 cases, 2 different publications described the same patient population and were counted as 1 study [7/22 and 20/21]. Finally, 33 studies were included in the synthesis [17-50]. 
Dementia

Cognitive Disorders
Dement Geriatr Cogn Disord 2013;36:263-278

DOI: 10.1159/000351679

Wahlster et al.: Clinical Assessment of Amyloid Imaging in Alzheimer's Disease:

A Systematic Review of the Literature

Table 1. Evaluation parameters for amyloid imaging in selected studies

\begin{tabular}{|c|c|c|c|c|c|}
\hline $\begin{array}{l}\text { Reference } \\
\text { (first author) }\end{array}$ & $\begin{array}{l}\text { Year of } \\
\text { publication }\end{array}$ & Reference test & Study population & Follow-up & $\begin{array}{l}\text { Amyloid imaging } \\
\text { interpretation }\end{array}$ \\
\hline $\begin{array}{l}\text { Forsberg } \\
{[40]}\end{array}$ & 2008 & $\begin{array}{l}\text { diagnosis AD/MCI, CSF A } \beta 1-42 \text {, } \\
\text { FDG-PET, EM (Rey Auditory Verbal } \\
\text { Learning and Retention as well as } \\
\text { Rey Osterrieth retention), MMSE }\end{array}$ & $6 \mathrm{HC}, 21 \mathrm{MCI}, 27 \mathrm{AD}$ & none & $\begin{array}{l}\text { quantitative, } \\
\text { continuous and } \\
\text { dichotomous }\end{array}$ \\
\hline Fripp [44] & 2008 & MMSE, EM & $18 \mathrm{HC}, 15 \mathrm{MCI}, 15 \mathrm{AD}$ & none & $\begin{array}{l}\text { quantitative, } \\
\text { continuous and } \\
\text { dichotomous }\end{array}$ \\
\hline Jack [27] & 2008 & $\begin{array}{l}\text { MRI, CDR-SB, MMSE, memory } \\
\text { performance with the WMS-R } \\
\text { visual reproduction II, WMS-R } \\
\text { logical memory II, AVLT delayed } \\
\text { recall and AVLT sum of learning } \\
\text { trials } 1-5\end{array}$ & $20 \mathrm{HC}, 17$ aMCI, 8 AD & none & $\begin{array}{l}\text { quantitative, } \\
\text { continuous and } \\
\text { dichotomous }\end{array}$ \\
\hline $\mathrm{Li}[36]$ & 2008 & $\begin{array}{l}\text { diagnostic efficiency, FDG-PET, } \\
\text { MMSE }\end{array}$ & $7 \mathrm{HC}, 13 \mathrm{MCI}, 17 \mathrm{AD}$ & none & $\begin{array}{l}\text { quantitative, } \\
\text { dichotomous }\end{array}$ \\
\hline Grimmer [42] & 2009 & CDR-SB & $32 \mathrm{AD}$ & none & $\begin{array}{l}\text { quantitative, } \\
\text { continuous }\end{array}$ \\
\hline Jack [29] & 2009 & MMSE, CDR, ApoE4 & $21 \mathrm{HC}, 32 \mathrm{MCI}, 8 \mathrm{AD}$ & 1 year & $\begin{array}{l}\text { quantitative, } \\
\text { continuous and } \\
\text { dichotomous }\end{array}$ \\
\hline $\begin{array}{l}\text { Mormino } \\
{[30]}\end{array}$ & 2009 & EM (RAVLT), structural MRI & 37 HC, 52 MCI, 35 AD & none & $\begin{array}{l}\text { quantitative, } \\
\text { continuous }\end{array}$ \\
\hline Morris [18] & 2009 & $\mathrm{CDR}$, diagnosis to $\mathrm{AD}$ & $\begin{array}{l}159 \mathrm{HC}, 9 \text { diagnosed } \\
\text { with AD during } \\
\text { follow-up }\end{array}$ & $0.8-5.5$ years & $\begin{array}{l}\text { quantitative, } \\
\text { continuous }\end{array}$ \\
\hline Okello [47] & 2009 & conversion rate to $\mathrm{AD}$ & $31 \mathrm{MCI}$ & 3 years & $\begin{array}{l}\text { quantitative, } \\
\text { dichotomous }\end{array}$ \\
\hline $\begin{array}{l}\text { Tolboom } \\
{[50]}\end{array}$ & 2009 & $\begin{array}{l}\text { cognitive function (MMSE, Digit } \\
\text { Span backward, Digit Span } \\
\text { forward, RAVLT immediate recall, } \\
\text { RAVLT delayed recall, VAT, VAT } \\
\text { picture naming, TMT A and B, } \\
\text { Stroop 1-3, category fluency, Rey } \\
\text { Figure Copy Test) }\end{array}$ & $12 \mathrm{AD}, 13 \mathrm{MCI}, 15 \mathrm{HC}$ & none & $\begin{array}{l}\text { quantitative, } \\
\text { continuous }\end{array}$ \\
\hline Tolboom [38] & 2009 & structural MRI, MMSE, RAVLT & $14 \mathrm{AD}, 11 \mathrm{MCI}, 13 \mathrm{HC}$ & none & $\begin{array}{l}\text { quantitative, } \\
\text { continuous }\end{array}$ \\
\hline Wolk [25] & 2009 & $\begin{array}{l}\text { standard psychometric battery of } \\
\text { attention, memory, language, } \\
\text { visuospatial construction, and } \\
\text { executive functions (MMSE), } \\
\text { structural MRI, diagnosis to AD }\end{array}$ & $26 \mathrm{MCI}$ & $\begin{array}{l}21.2 \text { months } \\
\text { (16 SD) }\end{array}$ & $\begin{array}{l}\text { quantitative, } \\
\text { dichotomous }\end{array}$ \\
\hline $\begin{array}{l}\text { Forsberg } \\
{[20,21]}\end{array}$ & $\begin{array}{l}2010 / \\
2012\end{array}$ & $\begin{array}{l}\text { diagnosis AD/MCI, CSF A } \beta 1-42 \text {, } \\
\text { FDG-PET, EM (RAVLT total } \\
\text { learning, RAVLT retention) }\end{array}$ & $6 \mathrm{HC}, 21 \mathrm{MCI}, 37 \mathrm{AD}$ & none & $\begin{array}{l}\text { quantitative, } \\
\text { dichotomous }\end{array}$ \\
\hline Jack [28] & 2010 & diagnosis of MCI to $\mathrm{AD}$ & 218 MCI & 2 years & $\begin{array}{l}\text { quantitative, } \\
\text { dichotomous }\end{array}$ \\
\hline $\begin{array}{l}\text { Resnick } \\
{[49]}\end{array}$ & 2010 & $\begin{array}{l}\text { MMSE, CVLT immediate recall, } \\
\text { CVLT delayed recall, Trails B }\end{array}$ & $51 \mathrm{HC}, 6 \mathrm{MCI}$ & $\begin{array}{l}\text { mean follow-up } \\
10.8 \text { years }\end{array}$ & $\begin{array}{l}\text { quantitative, } \\
\text { dichotomous }\end{array}$ \\
\hline $\begin{array}{l}\text { Pike [7]/ } \\
\text { Rowe [22] }\end{array}$ & $\begin{array}{l}2011 / \\
2010\end{array}$ & $\begin{array}{l}\text { ApoE status, CDR, MMSE and other } \\
\text { cognitive tests }\end{array}$ & $\begin{array}{l}177 \mathrm{HC}, 57 \mathrm{MCI}, \\
53 \mathrm{AD}\end{array}$ & none & $\begin{array}{l}\text { quantitative, } \\
\text { dichotomous }\end{array}$ \\
\hline
\end{tabular}


Table 1 (continued)

\begin{tabular}{|c|c|c|c|c|c|}
\hline $\begin{array}{l}\text { Reference } \\
\text { (first author) }\end{array}$ & $\begin{array}{l}\text { Year of } \\
\text { publication }\end{array}$ & Reference test & Study population & Follow-up & $\begin{array}{l}\text { Amyloid imaging } \\
\text { interpretation }\end{array}$ \\
\hline $\begin{array}{l}\text { Tolboom } \\
\text { [39] }\end{array}$ & 2010 & $\begin{array}{l}\text { diagnosis (specificity, sensitivity, } \\
\text { accuracy) }\end{array}$ & $20 \mathrm{HC}, 21 \mathrm{AD}$ & none & $\begin{array}{l}\text { visual ratings, } \\
\text { dichotomous and } \\
\text { quantitative }\end{array}$ \\
\hline $\begin{array}{l}\text { Chételat } \\
{[26]}\end{array}$ & 2011 & $\begin{array}{l}\text { EM composite score (RCFT, CVLT), } \\
\text { MMSE, structural MRI }\end{array}$ & $93 \mathrm{HC}, 43 \mathrm{MCI}, 34 \mathrm{AD}$ & none & $\begin{array}{l}\text { quantitative, } \\
\text { continuous }\end{array}$ \\
\hline $\begin{array}{l}\text { Koivunen } \\
{[45]}\end{array}$ & 2011 & $\begin{array}{l}\text { MMSE scores, structural MRI, } \\
\text { progression to AD }\end{array}$ & $13 \mathrm{HC}, 29 \mathrm{MCI}$ & 2 years & $\begin{array}{l}\text { quantitative, } \\
\text { dichotomous }\end{array}$ \\
\hline Lee [46] & 2011 & $\begin{array}{l}\text { MMSE, CDR, CDR-SB, GDS, PEPs, } \\
\text { attention, language, visuospatial } \\
\text { functions, memory, executive } \\
\text { functions }\end{array}$ & $\begin{array}{l}10 \mathrm{HC}, 45 \text { subcortical } \\
\text { vascular dementia, } \\
14 \mathrm{AD}\end{array}$ & none & $\begin{array}{l}\text { quantitative, } \\
\text { dichotomous }\end{array}$ \\
\hline $\begin{array}{l}\text { Marshall } \\
{[33]}\end{array}$ & 2011 & IADL & $19 \mathrm{HC}, 36 \mathrm{MCI}$ & none & $\begin{array}{l}\text { quantitative, } \\
\text { continuous }\end{array}$ \\
\hline Meyer [37] & 2011 & MMSE & $\begin{array}{l}4 \mathrm{MCI}, 15 \mathrm{AD}, 3 \\
\text { frontotemporal lobar } \\
\text { degeneration }\end{array}$ & none & $\begin{array}{l}\text { quantitative, } \\
\text { continuous }\end{array}$ \\
\hline $\begin{array}{l}\text { Rabinovici } \\
{[48]}\end{array}$ & 2011 & $\begin{array}{l}\text { specificity, sensitivity of diagnosis, } \\
\text { CDR, CDR-SB, MMSE, ApoE }\end{array}$ & $\begin{array}{l}25 \mathrm{HC}, 62 \mathrm{AD}, 45 \\
\text { frontotemporal lobar } \\
\text { degeneration }\end{array}$ & none & $\begin{array}{l}\text { quantitative, } \\
\text { visual rating and } \\
\text { dichotomous }\end{array}$ \\
\hline $\begin{array}{l}\text { Villemagne } \\
\text { [24] }\end{array}$ & 2011 & $\begin{array}{l}\text { EM composite score (RCFT, CVLT), } \\
\text { non-memory cognition score, } \\
\text { MMSE, CDR, diagnosis to AD }\end{array}$ & $\begin{array}{l}106 \mathrm{HC}, 65 \mathrm{MCI}, \\
35 \mathrm{AD}\end{array}$ & $\begin{array}{l}20 \text { months to } \\
3 \text { years }\end{array}$ & $\begin{array}{l}\text { quantitative, } \\
\text { continuous and } \\
\text { dichotomous }\end{array}$ \\
\hline Ewers [17] & 2012 & $\begin{array}{l}\text { ADAS-cog, RAVLT EM, predicting } \\
\text { conversion from MCI to AD }\end{array}$ & $\begin{array}{l}124 \mathrm{HC}, 229 \text { aMCI, } \\
112 \text { probable AD }\end{array}$ & 2 years & $\begin{array}{l}\text { quantitative, } \\
\text { dichotomous }\end{array}$ \\
\hline Furst [41] & 2012 & MMSE and CDR-SB & $39 \mathrm{AD}$ & none & $\begin{array}{l}\text { quantitative, } \\
\text { continuous and } \\
\text { dichotomous }\end{array}$ \\
\hline $\begin{array}{l}\text { Grimmer } \\
{[31]}\end{array}$ & 2012 & $\begin{array}{l}\text { ApoE4, CDR, diagnosis } \\
\text { (AD, other dementia) }\end{array}$ & $28 \mathrm{MCI}$ & 2 years & $\begin{array}{l}\text { quantitative, } \\
\text { dichotomous }\end{array}$ \\
\hline Kadir [43] & 2012 & $\begin{array}{l}\text { FSIQ, WAIS-R composites for } \\
\text { semantic memory, visuospatial } \\
\text { ability, short-term memory, EM, } \\
\text { attention with TMT A and B, ApoE, } \\
\text { FDG-PET }\end{array}$ & $5 \mathrm{MCI}, 9 \mathrm{AD}$ & $\begin{array}{l}3 \text { years for } \mathrm{MCI} \\
2 \text { and } 5 \text { years for } \\
\mathrm{AD}\end{array}$ & $\begin{array}{l}\text { quantitative, } \\
\text { continuous }\end{array}$ \\
\hline $\begin{array}{l}\text { Knopman } \\
{[19]}\end{array}$ & 2012 & $\begin{array}{l}\text { ApoE4, MMSE, cognitive z scores, } \\
\text { FDG-PET, structural MRI, diagnosis }\end{array}$ & $296 \mathrm{HC}$ & 1 year & $\begin{array}{l}\text { quantitative, } \\
\text { dichotomous }\end{array}$ \\
\hline $\begin{array}{l}\text { Koivunen } \\
{[32]}\end{array}$ & 2012 & $\begin{array}{l}\text { MMSE, psychometric test scores, } \\
\text { conversion rate }\end{array}$ & $16 \mathrm{aMCI}$ & 2 years & $\begin{array}{l}\text { quantitative, } \\
\text { dichotomous }\end{array}$ \\
\hline $\begin{array}{l}\text { Nordberg } \\
{[34]}\end{array}$ & 2012 & $\begin{array}{l}\text { MMSE, verbal and non-verbal } \\
\text { memory, visuoconstruction, verbal } \\
\text { fluency, ApoE, conversion rate }\end{array}$ & $51 \mathrm{HC}, 72 \mathrm{MCI}, 97 \mathrm{AD}$ & $\begin{array}{l}\text { 28-month } \\
\text { follow-up data of } \\
64 \text { MCI patients }\end{array}$ & $\begin{array}{l}\text { quantitative, } \\
\text { continuous and } \\
\text { dichotomous }\end{array}$ \\
\hline $\begin{array}{l}\text { Ossenkoppele } \\
\text { [35] }\end{array}$ & 2012 & MMSE, FDG-PET & $11 \mathrm{HC}, 12 \mathrm{MCI}, 8 \mathrm{AD}$ & $2.5(2-4)$ years & $\begin{array}{l}\text { quantitative, } \\
\text { continuous }\end{array}$ \\
\hline $\begin{array}{l}\text { Ossenkoppele } \\
{[23]}\end{array}$ & 2013 & diagnosis, FDG-PET & $\begin{array}{l}154 \text { dementia patients } \\
\text { (different diagnosis) }\end{array}$ & $\begin{array}{l}2 \text { years for } \\
39 \text { patients }\end{array}$ & $\begin{array}{l}\text { visual rating, } \\
\text { dichotomous }\end{array}$ \\
\hline
\end{tabular}

aMCI = Amnestic MCI; AVLT = Auditory Verbal Learning Test; CVLT = California Verbal Learning Test; FDG-PET = fluorodeoxyglucose $\left({ }^{18} \mathrm{~F}\right)$ positron emission tomography; FSIQ = Full Scale IQ; GDS = Global Deterioration Scale; HC = healthy controls; PEPs = peripheral ethanolamine plasmalogens; RCFT = Rey Complex Figure Test; TMT = Trail Making Test; VAT = Visual Association Test; WAIS-R = Wechsler Adult Intelligence Scale-Revised; WMS-R = Wechsler Memory Scale-Revised. 
Table 2. Cognitive parameters

\begin{tabular}{|c|c|c|c|}
\hline $\begin{array}{l}\text { Cognitive } \\
\text { test }\end{array}$ & Population & $\begin{array}{l}\text { Correlations/regression to amyloid } \\
\text { deposition }\end{array}$ & Follow-up changes \\
\hline MMSE & $\begin{array}{l}\text { HC, MCI, AD } \\
\text { HC, MCI, AD } \\
\text { HC, MCI, AD } \\
\text { HC, MCI, AD } \\
\text { AD } \\
\text { MCI, AD } \\
\text { AD } \\
\text { HC, MCI, AD } \\
\text { HC, MCI, AD } \\
\text { HC, MCI, AD } \\
\text { HC, MCI } \\
\text { HC, MCI, AD }\end{array}$ & $\begin{array}{l}\text { not significant [27], } r=-0.25, p=0.09 \\
\beta=-0.66, R^{2}=0.52, p<0.01[50] \\
r=-0.75, p<0.001[38] \\
\text { no correlation [41] } \\
\text { no correlation [37] }\end{array}$ & $\begin{array}{l}\mathrm{r}=-0.38, \mathrm{p}=0.04[24] \\
\mathrm{r}_{\mathrm{s}}=-0.42(\mathrm{p}<0.05)[35] \\
\text { not significant, } \mathrm{r}=-0.22 \\
\mathrm{p}=0.09[29] \\
\text { annual decline of } 0.13 \text { (linear } \\
\text { mixed model), } \mathrm{p}<0.05[49]\end{array}$ \\
\hline EM & $\begin{array}{l}\text { HC, MCI } \\
\text { HC, MCI } \\
\text { MCI } \\
\text { MCI } \\
\text { HC, MCI } \\
\text { MCI, AD } \\
\text { HC, MCI, AD } \\
\text { HC, MCI, AD } \\
\text { HC, MCI, AD } \\
\text { MCI }\end{array}$ & $\begin{array}{l}\mathrm{R}^{2}=0.17, \mathrm{p}=0.049[30] \text { (to RAVLT) } \\
\mathrm{r}=-0.59, \mathrm{p}<0.001[24] \\
\mathrm{r}=-0.57, \mathrm{p}<0.0001[24] \\
\mathrm{r}=-0.45, \mathrm{p}<0.043[40] \\
\mathrm{R}^{2}=0.378, \mathrm{p}<0.001[26] \\
\mathrm{r}=-0.42, \mathrm{p}=0.004[20] \text { (to RAVLT) } \\
\beta=-0.76, \mathrm{R}^{2}=0.57, \mathrm{p}<0.01 \text { [50] (to RAVLT) } \\
\mathrm{r}=-0.63, \mathrm{p}<0.0001[38] \text { (to RAVLT) } \\
\mathrm{r}=0.71[44]\end{array}$ & $\begin{array}{l}\text { difference between amyloid- } \\
\text { positive and -negative subjects: } \\
\beta=-0.44, p=0.01 \text { [17] (to RAVLT) }\end{array}$ \\
\hline CDR & $\begin{array}{l}\text { HC, MCI, AD } \\
\text { AD } \\
\text { AD } \\
\text { HC, MCI, AD } \\
\text { HC, MCI, AD }\end{array}$ & $\begin{array}{l}\mathrm{R}^{2}=0.106-0.219, \mathrm{p}<0.05[42] \\
\text { no correlation }[41] \\
\mathrm{r}_{\mathrm{s}}=0.54, \mathrm{p}<0.001[27]\end{array}$ & $\begin{array}{l}\text { no significant correlation [18] } \\
\text { no correlation [29] }\end{array}$ \\
\hline ADAS-cog & MCI & & $\begin{array}{l}\text { difference between amyloid- } \\
\text { positive and -negative subjects: } \\
\beta=1.42 \text { ADAS-cog/year, } \\
p<0.001[17]\end{array}$ \\
\hline IADL & $\begin{array}{l}\mathrm{HC}, \mathrm{MCI} \\
\mathrm{MCI}\end{array}$ & $\begin{array}{l}\beta=5.8, R^{2}=0.40, p<0.001[33] \\
\beta=6.1, R^{2}=0.28, p=0.003[33]\end{array}$ & \\
\hline
\end{tabular}

Table 1 summarizes the findings for different clinically relevant endpoints for AD. The interpretation of amyloid imaging was mostly performed in a quantitative, continuous manner. Amyloid imaging was assessed using the following clinically relevant cognitive measures: Mini-Mental State Examination (MMSE), Clinical Dementia Rating (CDR) and Clinical Dementia Rating Sum Boxes (CDR-SB), Instrumental Activities of Daily Living (IADL), Alzheimer Disease Assessment Scale - Cognitive Subscale (ADAS-cog), Episodic Memory (EM) measured by means of the Rey Auditory Verbal Learning Test (RAVLT) and others as well as diagnosis (healthy and MCI to AD) and prognosis (healthy and MCI to AD). 
Dementia

Cognitive Disorders

\begin{tabular}{l|l}
\hline \multicolumn{2}{l}{ Dement Geriatr Cogn Disord 2013;36:263-278 } \\
\hline DOI: $\underline{10.1159 / 000351679}$ & $\begin{array}{l}\text { C) 2013 S. Karger AG, Basel } \\
\text { www.karger.com/dem }\end{array}$ \\
\hline
\end{tabular}

Wahlster et al:: Clinical Assessment of Amyloid Imaging in Alzheimer's Disease: A Systematic Review of the Literature

\section{Cognitive Parameters}

A summary of the correlations of amyloid load to cognitive parameters is shown in table 2. Correlations between [C-11]PiB imaging and CDR-SB were assessed by 5 studies [18, $27,29,41,42]$, but only 2 detected significant correlations. One study only found a very weak correlation for patients with AD ( $\mathrm{r}=0.106-0.219)$ whereas another stated an intermediate correlation of $54 \%(\mathrm{p}<0.001)$ [29].

Another cognitive parameter is the EM composite score [17, 20, 24, 26, 30, 40, 44, 50]. The correlations range from -0.42 [20] up to -0.71 [44] for different patient groups. A linear regression model of amyloid imaging as a predictor, including age, gender and years of education as covariates, could predict the EM scores for healthy and MCI subjects with $37.8 \%$ $(p<0.001)$ [26]. The independent variable of frontal PiB load was a good predictor, with $57 \%$ for RAVLT delayed recall adjusted for age and $\operatorname{sex}\left(\beta=-0.76, \mathrm{R}^{2}=0.57, \mathrm{p}<0.01\right)$ [50]. However, no significant correlations of amyloid load to cognition in episodic memory and other parameters for MCI and AD patients were found in a study with a 3- to 5-year follow-up [43]. Another follow-up study of MCI patients converting to AD and higher baseline [C-11]PiB uptake detected a decline in word list saving memory $(r=0.73, p<0.05)$ and a decline in the Stroop interference score $(r=-1.00, p<0.01)$ [32].

The most extensively examined cognitive parameter was MMSE in 12 studies [24, 27, 29, $34,35,37,38,41,44,46,49,50]$. Correlations for MMSE ranged from -0.45 up to -0.75 based on mixed populations of healthy, MCI and AD subjects. The author who stated the strongest correlation of $0.75(p<0.001)$ [38] reported in a different study a prediction of $52 \%$ between MMSE and $[\mathrm{C}-11] \mathrm{PiB}$ load $\left(\beta=-0.66, \mathrm{R}^{2}=0.52, \mathrm{p}<0.01\right)$ in a linear regression model adjusted for age and sex [50]. The MMSE was found to be lower in amyloid-positive patients (18.6 in amyloid-positive vs. 22.6 in amyloid-negative patients, $\mathrm{p}<0.001$ ) [46].

During follow-up, changes in amyloid retention could predict changes in MMSE with correlations from -0.27 up to $-0.42[24,29,35]$. One study suggested an annual decline of $0.13(\mathrm{p}=0.05)$ by high amyloid burden adjusted for age and education [49]. Other research groups found a negative correlation between [C-11]PiB and MMSE [37, 41].

Amyloid load also correlated with IADL in a linear multiple regression model with the predictors global PiB retention, age, IQ, MMSE and RAVLT delayed recall. The predictive value was $40 \%\left(\beta=5.8, R^{2}=0.40, p<0.001\right)$ for healthy and MCI subjects and still $28 \%(\beta=6.1$, $\mathrm{R}^{2}=0.28, \mathrm{p}=0.003$ ) for MCI patients excluding the predictors MMSE and RAVLT [33]. Regarding the ADAS-cog, the difference between amyloid-positive and -negative MCI patients was 1.42 ADAS-cog/year calculated by 2-year follow-up ( $<<0.001)$ [17].

\section{Diagnosis}

Amyloid imaging was also used for the diagnosis of AD within the 5 studies shown in table $3[22,23,36,39,48]$. The sensitivity and specificity of amyloid imaging ranged between 62 and $100 \%$, depending on the examined population and on how data interpretation was undertaken. Accuracy ranged from 70 to $97 \%$. [C-11]PiB-PET also contributed to the diagnostic certainty in terms of different types of dementia (23-28\%) [23].

\section{Prediction of Conversion}

Nine studies assessed amyloid imaging regarding the predictive value for conversion shown in table 4. Four studies assessed the risk of conversion during a 2-year follow-up for amyloid-negative MCI patients. This risk ranged from 0 to 19\% [28, 31]. During a 20-month follow-up study, there was a $98 \%$ chance to stay cognitively stable for amyloid-negative patients. The risk of conversion to $\mathrm{MCI}$ or $\mathrm{AD}$ was $16 \%$ for amyloid-positive healthy patients.

The conversion of amyloid-positive MCI patients ranged from 38\% [25] to 86\% [23] within a 2-year follow-up. MCI patients who converted to AD had significantly higher PiB 
Dementia

and Geriatric

Cognitive Disorders
Wahlster et al.: Clinical Assessment of Amyloid Imaging in Alzheimer's Disease A Systematic Review of the Literature

Table 3. Diagnostic value of amyloid imaging

\begin{tabular}{|c|c|c|}
\hline Diagnostic parameter & Population & Value \\
\hline Sensitivity & $\begin{array}{l}\text { HC, AD } \\
\text { HC, AD, frontotemporal lobar degeneration } \\
\text { HC, AD } \\
\text { HC, AD } \\
\text { HC, MCI } \\
\text { MCI, AD }\end{array}$ & $\begin{array}{l}98 \%[22] \\
89-90 \%[48] \\
100 \%[39] \\
94 \%[36] \\
62 \%[36] \\
94 \%[36]\end{array}$ \\
\hline Specificity & $\begin{array}{l}\text { HC, AD } \\
\text { HC, AD, frontotemporal lobar degeneration } \\
\text { HC, AD } \\
\text { HC, AD } \\
\text { HC, MCI } \\
\text { MCI, AD }\end{array}$ & $\begin{array}{l}66 \%[22] \\
82-84 \%[48] \\
85 \%[39] \\
100 \%[36] \\
100 \%[36] \\
62 \%[36]\end{array}$ \\
\hline Accuracy & $\begin{array}{l}\text { HC, AD } \\
\text { HC, AD, frontotemporal lobar degeneration } \\
\text { HC, AD } \\
\text { HC, AD } \\
\text { HC, MCI } \\
\text { MCI, AD }\end{array}$ & $\begin{array}{l}73 \%[22] \\
97 \%[48] \\
93 \%[39] \\
96 \%[36] \\
75 \%[36] \\
70 \%[36]\end{array}$ \\
\hline Positive predictive value & $\mathrm{HC}, \mathrm{AD}$, frontotemporal lobar degeneration & $89 \%[48]$ \\
\hline Negative predicted value & $\mathrm{HC}, \mathrm{AD}$, frontotemporal lobar degeneration & $84 \%[48]$ \\
\hline Positive likelihood ratio & $\begin{array}{l}\mathrm{HC}, \mathrm{AD} \\
\mathrm{HC}, \mathrm{AD} \text {, frontotemporal lobar degeneration }\end{array}$ & $\begin{array}{l}6.7[39] \\
5.3[48]\end{array}$ \\
\hline Negative likelihood ratio & $\begin{array}{l}\mathrm{HC}, \mathrm{AD} \\
\mathrm{HC}, \mathrm{AD} \text {, frontotemporal lobar degeneration }\end{array}$ & $\begin{array}{l}0[39] \\
0.1[48]\end{array}$ \\
\hline Contribution to diagnostic certainty & $\begin{array}{l}\text { AD } \\
\text { MCI } \\
\text { different kinds of dementia }\end{array}$ & $\begin{array}{l}23 \%[23] \\
27 \%[23] \\
28 \%[23]\end{array}$ \\
\hline
\end{tabular}

$\mathrm{HC}=$ Healthy controls .

uptake in various areas compared to stable MCI patients $(\mathrm{p}<0.005)$ within a period of 2 years [32, 45]. An extensive study with $218 \mathrm{MCI}$ patients showed that amyloid-positive patients were more likely to convert to AD (50 vs. 19\% of amyloid-negative patients) during 2 years. Besides, amyloid load could predict the time to progression within all patients. However, magnetic resonance imaging (MRI) was more successful in predicting the time to progression for amyloid-positive patients [28]. One study calculated a hazard ratio of $4.82(\mathrm{p}<0.05)$ for conversion of healthy subjects to $\mathrm{AD}$ with follow-up times between 0.8 and 5.5 years [18]. A large multi-center study provided 28-month follow-up of $64 \mathrm{MCI}$ patients. None of the amyloid-negative patients converted to $\mathrm{AD}$, whereas a conversion rate of $25 \%$ per annum was calculated for amyloid-positive patients [34]. Another study validated these results: $80.7 \%$ of the amyloid-positive subjects converted from MCI to AD within 2 years, but only $16.6 \%$ of the amyloid-negative subjects [17]. The application of the new NIA-AA preclinical AD criteria concluded that amyloid-positive status alone was associated with $17 \%$ progression within the three preclinical stages during 1 year [19]. 
Wahlster et al.: Clinical Assessment of Amyloid Imaging in Alzheimer's Disease: A Systematic Review of the Literature

Table 4. Predictive value of amyloid imaging

\begin{tabular}{|c|c|c|c|}
\hline Predictive value & $\begin{array}{l}\text { Popu- } \\
\text { lation }\end{array}$ & Follow-up & Value \\
\hline $\begin{array}{l}\text { Risk of conversion for amyloid- } \\
\text { negative patients }\end{array}$ & MCI & $\begin{array}{l}2 \text { years } \\
2 \text { years } \\
2 \text { years } \\
2 \text { years }\end{array}$ & $\begin{array}{l}19 \%[28] \\
16.6 \%[17] \\
0 \%[23] \\
0 \%[31]\end{array}$ \\
\hline $\begin{array}{l}\text { Risk of conversion for amyloid- } \\
\text { positive patients }\end{array}$ & MCI & $\begin{array}{l}1 \text { year } \\
20 \text { months } \\
3 \text { years } \\
2 \text { years } \\
2 \text { years } \\
2 \text { years } \\
20 \text { months } \\
2 \text { years } \\
28 \text { months } \\
3 \text { years } \\
21 \text { months }\end{array}$ & $\begin{array}{l}\text { 17\% progression within preclinical stages }[19] \\
16 \% \text { (to MCI, AD) [24] } \\
25 \% \text { (to MCI, AD) [24] } \\
80.7 \%[17] \\
86 \%[23] \\
53 \%[31] \\
67 \%[24] \\
50 \%[28] \\
67.4 \% \text { (calculated per annum: } 25 \% \text { ) }[34] \\
82 \%, p<0.01[47] \\
38 \%, p=0.046[25]\end{array}$ \\
\hline Accuracy for follow-up diagnosis & MCI & 2 years & $70 \%$ [31] \\
\hline
\end{tabular}

$\mathrm{HC}=$ Healthy controls.

Societal benefit
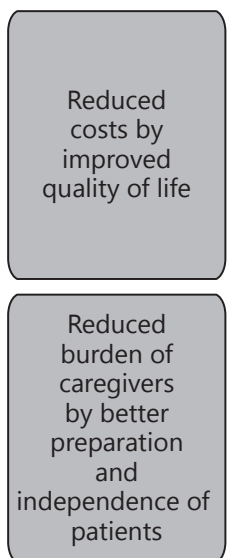

Medical benefit
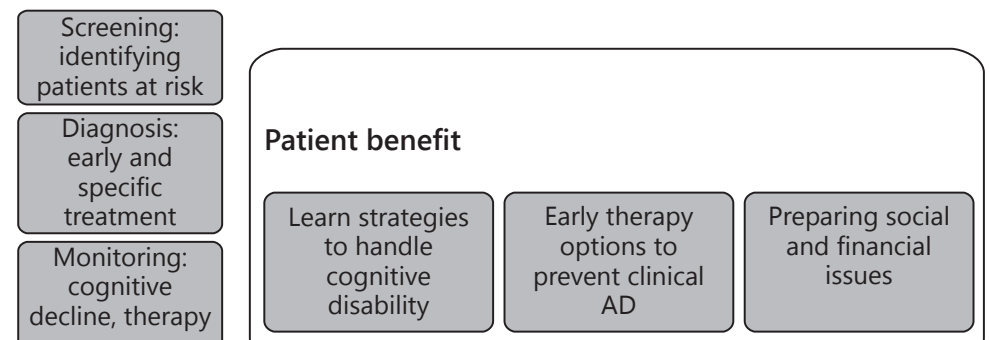

Fig. 2. Potential benefit of preclinical diagnosis of AD by amyloid imaging. 
Dementia

and Geriatric

Cognitive Disorders

\begin{tabular}{l|l}
\hline Dement Geriatr Cogn Disord 2013;36:263-278 \\
\hline DOI: $\underline{10.1159 / 000351679}$ & $\begin{array}{l}\text { ( ) 2013 S. Karger AG, Basel } \\
\text { www.karger.com/dem }\end{array}$ \\
\hline
\end{tabular}

Wahlster et al.: Clinical Assessment of Amyloid Imaging in Alzheimer's Disease: A Systematic Review of the Literature

\section{Discussion}

An extensive literature search was conducted to compile a state-of-the-art overview of amyloid imaging via [C-11]PiB-PET. The evidence shows a potential benefit of amyloid imaging in terms of predictive information and diagnosis (fig. 2).

\section{Correlations to Cognitive Criteria}

Several studies found correlations between amyloid status and cognitive measures. These correlations depended on the study population (AD, MCI, MCI + AD, MCI + AD + healthy). The most extensively studied cognitive measures were MMSE and EM. As the results of this review suggest, amyloid imaging is not a good predictor for cognitive performance [24, 42]. However, the link between cognition and amyloid status was stronger for MCI patients. Overall, the predictive value of amyloid imaging for cognitive performance was weak $[24,29$, $35,41,49]$ and even non-existent regarding CDR $[18,29]$. This result was confirmed in healthy older persons post mortem [51]. A possible explanation is that amyloid deposition may occur before cognitive symptoms are seen [26]. Alternatively, amyloid-independent factors can contribute according to the second pathway hypothesis. This could be a hint to cognitive decline across AD and MCI patients as well as healthy subjects [35]. Structural brain measures such as MRI and fluorodeoxyglucose PET (FDG-PET) are more accurate than amyloid imaging to detect cognitive performance as the time frame of the pathologic process suggests [43]. Amyloid burden affects hippocampal atrophy and structural decline affects cognition. Therefore, the link between amyloid load and cognition is indirectly bridged by structural decline.

\section{Diagnostic Value}

It is important to separately assess the diagnostic value of amyloid imaging for different kinds of dementia $[23,46]$. The likelihood of being amyloid-positive is increased in mild AD in comparison to prodromal AD [32]. In these cases, amyloid imaging contributes to a more exact diagnosis. The diagnostic criteria of the National Institute of Neurological and Communicative Disorders and Stroke (NINCDS) as well as the Alzheimer's Disease and Related Disorders Association (ADRDA) provide a sensitivity of $81 \%$ and a specificity of $70 \%$ [52]. Amyloid imaging seems to improve diagnosis with a sensitivity of $98 \%$ [22] or 89-90\% [48] and a specificity of $66 \%$ [22] or $82-84 \%$ [48]. These values satisfy the requirements of the National Institute on Aging Working Group on Molecular and Biochemical Markers of Alzheimer's Disease 'to detect a fundamental feature of neuropathology and be validated in neuro-pathologically-confirmed cases. According to the working group sensitivity of larger than $80 \%$ for detecting $\mathrm{AD}$ and a specificity of larger than $80 \%$ for distinguishing other dementias is required. In addition, the test should be reliable, reproducible, non-invasive, simple to perform and inexpensive' [53]. Still, the diagnosis of AD via PET needs to be coupled 'with a more comprehensive approach to the diagnostic process' [54]. The technical efficiency for a standard quantitative analysis, criteria and cut-off values of amyloid deposition and the significant brain regions are still in question. A critical point is that not all AD patients are amyloid-positive [41].

\section{Predictive Value to Conversion}

The detection of amyloid plaques before diagnosis is important in order to identify the preclinical stage of AD pathology. This was already claimed by post mortem studies in 1999 [55]. Amyloid imaging is a unique opportunity to identify preclinical AD patients without meeting clinical criteria for AD. Several studies confirmed that MCI patients with amyloidpositive status are at high risk of developing $\operatorname{AD}[17,25,28,34,47]$. 


\section{Context of Other Biomarkers}

All clinical benefits of amyloid imaging are increased by combining it with other biomarkers. The highest correlation to cognitive performance was achieved by a combination of imaging biomarkers (hippocampal atrophy + perforant path atrophy + temporal PiB) [26]. The diagnostic uncertainty can be optimally decreased by combining the diagnostic contribution of PiB and FDG-PET scans with other biomarkers [23]. Biomarkers of neuronal injury are not specific for $\mathrm{AD}$, but can provide information about progression of disease from the $\mathrm{MCI}$ to the AD state. In a hypothetical framework for structural and amyloid information, the likelihood for amyloid-positive patients without positive indicators of neuronal injury is only intermediate. Patients who had positive results for both biomarkers had the highest likelihood of progression from MCI to AD [56]. Genetic tests like the one for apolipoprotein E (ApoE) can help select patients for imaging. Several studies showed a higher amyloid burden and progression to AD in healthy subjects and MCI and AD patients with positive ApoE4 status $[45,47]$. Data mining approaches can help understand amyloid imaging in the context of other biomarkers. At the moment, the evidence for combining different biomarkers is still fragmented. The complexity of neurodegenerative disease needs adequate multimodal approaches to identify patient subgroups with similar characteristics.

\section{Treatment Options}

The impact of amyloid imaging will increase if an anti-amyloid therapy becomes available, which makes continuous monitoring of the amyloid load necessary. Several clinical trials are assessing potential candidates for anti-amyloid therapy. One study [57] highlights the use of amyloid imaging to assess the success of a new anti-amyloidal antibody therapy. The [C-11] PiB retention rate decreased by $0.09(\mathrm{p}=0.014)$ for $\mathrm{AD}$ patients and increased by 0.15 $(p=0.022)$ for the control group, but without significant impact on cognitive decline. These results and the latest failure of two phase 3 studies on bapineuzumab need to be considered regarding the missing treatment benefit on cognition and functional parameters [58]. In contrast, a meta-analysis of two studies about another amyloid monoclonal antibody (solanezumab) showed a significant cognitive benefit on each measure with solanezumab versus placebo for patients with mild AD, and also $18 \%$ less functional decline $(p=0.045)$ [59]. Another phase 3 study of solanezumab in patients with mild AD is planned. Additionally, several secondary prevention trials with amyloid-positive patients in the preclinical stage are currently ongoing: the Alzheimer's Prevention Initiative (API), the Dominantly Inherited Alzheimer Network (DIAN) and the Amyloid Treatment of Asymptomatic Alzheimer's Disease (A4) trial [60]. As in cancer, Sperling et al. [8] suggest to treat AD as early as possible, 'before significant cognitive impairment in the preclinical stage of AD'. Furthermore, AD should be defined as 'encompassing the underlying pathophysiological disease process'. Patients can mostly benefit from early therapeutic interventions before irreversible cognitive loss. The Australian Imaging, Biomarkers and Lifestyle (AIBL) study confirmed that amyloid deposition increased with the age of the subjects. The uptake changed from $18 \%$ in the group of people aged 60-69 years to $83 \%$ in the group aged over 85 years, which shows a time lag of 15 years between amyloid-positive status and AD prevalence [22].

\section{Cost-Effectiveness}

There have been no studies about the cost-effectiveness of amyloid imaging yet. A PET scan using a radiotracer causes costs of approximately USD 700 [61]. A recently published Markov simulation to assess MRI for screening of AD showed that screening is only costeffective with a very high diagnostic accuracy and effective treatment options [62]. A facename-based memory test adjusted to amyloid load could substitute imaging for screening in a broad population [63]. Selecting and stratifying patient subgroups is important for expen- 
Wahlster et al.: Clinical Assessment of Amyloid Imaging in Alzheimer's Disease:

A Systematic Review of the Literature

sive treatments. A model of the Levin group for the Alzheimer's Association shows that a hypothetical treatment that delayed the onset of clinical symptoms by 5 years could reduce the number of patients by $57 \%$, with corresponding cost reductions. A diagnostic instrument like PET imaging with $90 \%$ sensitivity and specificity in combination with a treatment that reduces cognitive decline by $50 \%$ would reduce the lifetime risk of dementia of a 65 -year-old person from 10.5 to $5.7 \%$ [64].

\section{Ethical Considerations}

There remain clinical and ethical questions on the value of amyloid imaging as long as there is no appropriate treatment. One can argue that patients can make plans for their remaining life when clinical symptoms occur [65]. On the other hand, a diagnosis can diminish the remaining quality of life when patients worry about being at risk. If risky treatments are available only for certain dementia subgroups, amyloid imaging can reduce the harm caused by side effects. Therefore, early biomarkers require a very high accuracy.

\section{Limitations of the Study}

Nearly all included studies were conducted in populations meeting standard clinical research criteria, with virtually no post mortem confirmation of the underlying pathology. A spectrum bias may exist because different $\mathrm{MCI}$ and dementia subtypes could affect the transferability of the diagnostic performance. Additionally, 3 years have proved too short a followup time to make final conclusions about the predictive value of amyloid imaging [22]. Highquality evidence like randomized controlled trials of PET diagnostic studies is still rare [66]. We only assessed [C-11]PiB for amyloid imaging. There are also important fluorine-18-labelled radiotracers for broad clinical application because the half-life of fluorine-18 is many times longer than that of [C-11]PiB. Still, [C-11] PiB is the option most widely used [10], and evidence suggests that its usefulness is transferable to other radiotracers such as fluorine-18 florbetapir [67].

\section{Conclusion}

This study highlights the current status of amyloid imaging in AD. Imaging is not used in clinical practice yet, although it can provide substantial benefits in special aspects of diagnostic accuracy, e.g. stratifying patient subgroups. In terms of preclinical diagnosis, it offers an opportunity for diagnosis in the time period of up to 10 years before clinical diagnosis. This is particularly interesting from an epidemiological viewpoint, regarding the increasing prevalence of amyloid deposition and later AD. Preclinical diagnosis can be a base for early, more effective treatment options. Approaches to combine different biomarkers can help increase the value of amyloid imaging. As the economic and societal burden of $\mathrm{AD}$ is increasing, research is required to develop and implement biomarkers for early screening, accurate diagnosis and monitoring of treatment. Improved diagnostics can improve patients' outcomes and reduce costs. In this context, amyloid imaging provides the key to understanding the early pathologic process in AD.

\section{Acknowledgment}

This project is part of the Cluster of Excellence 'Medical Technologies' and is supported by the German Federal Ministry of Education and Research (BMBF), project grant No. 01EX1013B. 
Wahlster et al.: Clinical Assessment of Amyloid Imaging in Alzheimer's Disease:

A Systematic Review of the Literature

\section{Disclosure Statement}

The authors report no competing interests.

\section{References}

- 1 Gustavsson A, Svensson M, Jacobi F, Allgulander C, Alonso J, Beghi E, Dodel R, Ekman M, Faravelli C, Fratiglioni L, Gannon B, Jones DH, Jennum P, Jordanova A, Jonsson L, Karampampa K, Knapp M, Kobelt G, Kurth T, Lieb R, Linde M, Ljungcrantz C, Maercker A, Melin B, Moscarelli M, Musayev A, Norwood F, Preisig M, Pugliatti M, Rehm J, Salvador-Carulla L, Schlehofer B, Simon R, Steinhausen HC, Stovner LJ, Vallat JM, den Bergh PV, van Os J, Vos P, Xu W, Wittchen HU, Jonsson B, Olesen J: Cost of disorders of the brain in Europe 2010. Eur Neuropsychopharmacol 2011;21:718-779.

- 2 Bond M, Rogers G, Peters J, Anderson R, Hoyle M, Miners A, Moxham T, Davis S, Thokala P, Wailoo A, Jeffreys $\mathrm{M}$, Hyde C: The effectiveness and cost-effectiveness of donepezil, galantamine, rivastigmine and memantine for the treatment of Alzheimer's disease (review of Technology Appraisal No. 111): a systematic review and economic model. Health Technol Assess 2012;16:1-470.

- 3 Djalalov S, Yong J, Beca J, Black S, Saposnik G, Musa Z, Siminovitch K, Moretti M, Hoch JS: Genetic testing in combination with preventive donepezil treatment for patients with amnestic mild cognitive impairment: an exploratory economic evaluation of personalized medicine. Mol Diagn Ther 2012;16:389-399.

4 Meyer JH: Neuroimaging markers of cellular function in major depressive disorder: implications for therapeutics, personalized medicine, and prevention. Clin Pharmacol Ther 2012;91:201-214.

5 Simpson S, Packer C, Stevens A, Raftery J: Predicting the impact of new health technologies on average length of stay: development of a prediction framework. Int J Technol Assess Health Care 2005;21:487-491.

6 Petersen RC, Parisi JE, Dickson DW, Johnson KA, Knopman DS, Boeve BF, Jicha GA, Ivnik RJ, Smith GE, Tangalos EG, Braak H, Kokmen E: Neuropathologic features of amnestic mild cognitive impairment. Arch Neurol 2006; 63:665-672.

7 Pike KE, Ellis KA, Villemagne VL, Good N, Chételat G, Ames D, Szoeke C, Laws SM, Verdile G, Martins RN, Masters CL, Rowe CC: Cognition and beta-amyloid in preclinical Alzheimer's disease: data from the AIBL study. Neuropsychologia 2011;49:2384-2390.

- 8 Sperling RA, Aisen PS, Beckett LA, Bennett DA, Craft S, Fagan AM, Iwatsubo T, Jack CR, Kaye J, Montine TJ, Park DC, Reiman EM, Rowe CC, Siemers E, Stern Y, Yaffe K, Carrillo MC, Thies B, Morrison-Bogorad M, Wagster MV, Phelps CH: Toward defining the preclinical stages of Alzheimer's disease: recommendations from the National Institute on Aging-Alzheimer's Association workgroups on diagnostic guidelines for Alzheimer's disease. Alzheimers Dement 2011;7:280-292.

- 9 Yang L, Rieves D, Ganley C: Brain amyloid imaging - FDA approval of florbetapir F18 injection. N Engl J Med 2012;367:885-887.

10 Mori T, Maeda J, Shimada H, Higuchi M, Shinotoh H, Ueno S, Suhara T: Molecular imaging of dementia. Psychogeriatrics 2012;12:106-114.

11 Richardson WS, Wilson MC, Nishikawa J, Hayward RS: The well-built clinical question: a key to evidence-based decisions. ACP J Club 1995;123:A12-A13.

12 Lopresti BJ, Klunk WE, Mathis CA, Hoge JA, Ziolko SK, Lu X, Meltzer CC, Schimmel K, Tsopelas ND, DeKosky ST, Price JC: Simplified quantification of Pittsburgh compound B amyloid imaging PET studies: a comparative analysis. J Nucl Med 2005;46:1959-1972.

13 Zhou Y, Resnick SM, Ye W, Fan H, Holt DP, Klunk WE, Mathis CA, Dannals R, Wong DF: Using a reference tissue model with spatial constraint to quantify [11C] Pittsburgh compound B PET for early diagnosis of Alzheimer's disease. Neuroimage 2007;36:298-312.

14 Moher D, Liberati A, Tetzlaff J, Altman DG; PRISMA Group: Preferred reporting items for systematic reviews and meta-analyses: the PRISMA statement. PLoS Med 2009;6:e1000097.

15 Fryback DG, Thornbury JR: The efficacy of diagnostic imaging. Med Decis Making 1991;11:88-94.

16 Whiting P, Weswood M, Rutjes A, Reitsma J, Bossuyt P, Kleijnen J: Evaluation of QUADAS, a tool for the quality assessment of diagnostic accuracy studies. BMC Med Res Methodol 2006;6:9.

$\checkmark 17$ Ewers M, Insel P, Jagust WJ, Shaw L, Trojanowski JQ, Aisen P, Petersen RC, Schuff N, Weiner MW: CSF biomarker and PIB-PET-derived beta-amyloid signature predicts metabolic, gray matter, and cognitive changes in nondemented subjects. Cereb Cortex 2012;22:1993-2004.

18 Morris JC, Roe CM, Grant EA, Head D, Storandt M, Goate AM, Fagan AM, Holtzman DM, Mintun MA: Pittsburgh compound B imaging and prediction of progression from cognitive normality to symptomatic Alzheimer disease. Arch Neurol 2009;66:1469-1475.

19 Knopman DS, Jack CR Jr, Wiste HJ, Weigand SD, Vemuri P, Lowe V, Kantarci K, Gunter JL, Senjem ML, Ivnik RJ, Roberts RO, Boeve BF, Petersen RC: Short-term clinical outcomes for stages of NIA-AA preclinical Alzheimer disease. Neurology 2012;78:1576-1582.

20 Forsberg A, Almkvist O, Engler H, Wall A, Långström B, Nordberg A: High PIB retention in Alzheimer's disease is an early event with complex relationship with CSF biomarkers and functional parameters. Curr Alzheimer Res 2010;7:56-66. 
Wahlster et al.: Clinical Assessment of Amyloid Imaging in Alzheimer's Disease:

A Systematic Review of the Literature

-21 Forsberg A, Engler H, Blomquist G, Långström B, Nordberg A: The use of PIB-PET as a dual pathological and functional biomarker in AD. Biochim Biophys Acta 2012;1822:380-385.

22 Rowe CC, Ellis KA, Rimajova M, Bourgeat P, Pike KE, Jones G, Fripp J, Tochon-Danguy H, Morandeau L, O’Keefe G, Price R, Raniga P, Robins P, Acosta O, Lenzo N, Szoeke C, Salvado O, Head R, Martins R, Masters CL, Ames D, Villemagne VL: Amyloid imaging results from the Australian Imaging, Biomarkers and Lifestyle (AIBL) study of aging. Neurobiol Aging 2010;31:1275-1283.

-23 Ossenkoppele R, Prins ND, Pijnenburg YA, Lemstra AW, van der Flier WM, Adriaanse SF, Windhorst AD, Handels RL, Wolfs CA, Aalten P, Verhey FR, Verbeek MM, van Buchem MA, Hoekstra OS, Lammertsma AA, Scheltens $\mathrm{P}$, van Berckel BN: Impact of molecular imaging on the diagnostic process in a memory clinic. Alzheimers Dement 2013;9:414-421.

24 Villemagne VL, Pike KE, Chételat G, Ellis KA, Mulligan RS, Bourgeat P, Ackermann U, Jones G, Szoeke C, Salvado O, Martins R, O'Keefe G, Mathis CA, Klunk WE, Ames D, Masters CL, Rowe CC: Longitudinal assessment of A $\beta$ and cognition in aging and Alzheimer disease. Ann Neurol 2011;69:181-192.

25 Wolk DA, Price JC, Saxton JA, Snitz BE, James JA, Lopez OL, Aizenstein HJ, Cohen AD, Weissfeld LA, Mathis CA, Klunk WE, DeKosky ST: Amyloid imaging in mild cognitive impairment subtypes. Ann Neurol 2009;65:557568.

-26 Chételat G, Villemagne VL, Pike KE, Ellis KA, Bourgeat P, Jones G, O’Keefe GJ, Salvado O, Szoeke C, Martins RN, Ames D, Masters CL, Rowe C, Australian Imaging Biomarkers and Lifestyle Study of Ageing (AIBL) Research Group: Independent contribution of temporal beta-amyloid deposition to memory decline in the pre-dementia phase of Alzheimer's disease. Brain 2011;134:798-807.

27 Jack CR Jr, Lowe VJ, Senjem ML, Weigand SD, Kemp BJ, Shiung MM, Knopman DS, Boeve BF, Klunk WE, Mathis CA, Petersen RC: 11C PiB and structural MRI provide complementary information in imaging of Alzheimer's disease and amnestic mild cognitive impairment. Brain 2008;131:665-680.

28 Jack CR, Wiste HJ, Vemuri P, Weigand SD, Senjem ML, Zeng G, Bernstein MA, Gunter JL, Pankratz VS, Aisen PS, Weiner MW, Petersen RC, Shaw LM, Trojanowski JQ, Knopman DS: Brain beta-amyloid measures and magnetic resonance imaging atrophy both predict time-to-progression from mild cognitive impairment to Alzheimer's disease. Brain 2010;133:3336-3348.

29 Jack CR Jr, Lowe VJ, Weigand SD, Wiste HJ, Senjem ML, Knopman DS, Shiung MM, Gunter JL, Boeve BF, Kemp BJ, Weiner M, Petersen RC: Serial PIB and MRI in normal, mild cognitive impairment and Alzheimer's disease: implications for sequence of pathological events in Alzheimer's disease. Brain 2009;132:1355-1365.

-30 Mormino EC, Kluth JT, Madison CM, Rabinovici GD, Baker SL, Miller BL, Koeppe RA, Mathis CA, Weiner MW, Jagust WJ: Episodic memory loss is related to hippocampal-mediated $\beta$-amyloid deposition in elderly subjects. Brain 2009;132:1310-1323.

-31 Grimmer T, Wutz C, Drzezga A, Forster S, Forstl H, Ortner M, Perneczky R, Kurz A: The usefulness of amyloid imaging in predicting the clinical outcome after two years in subjects with mild cognitive impairment. Curr Alzheimer Res 2012;10:82-85.

-32 Koivunen J, Karrasch M, Scheinin NM, Aalto S, Vahlberg T, Nagren K, Helin S, Viitanen M, Rinne JO: Cognitive decline and amyloid accumulation in patients with mild cognitive impairment. Dement Geriatr Cogn Disord 2012;34:31-37.

-33 Marshall GA, Olson LE, Frey MT, Maye J, Becker JA, Rentz DM, Sperling RA, Johnson KA: Instrumental activities of daily living impairment is associated with increased amyloid burden. Dement Geriatr Cogn Disord 2011;31: 443-450.

-34 Nordberg A, Carter SF, Rinne J, Drzezga A, Brooks DJ, Vandenberghe R, Perani D, Forsberg A, Langstrom B, Scheinin N, Karrasch M, Nagren K, Grimmer T, Miederer I, Edison P, Okello A, Van Laere K, Nelissen N, Vandenbulcke M, Garibotto V, Almkvist O, Kalbe E, Hinz R, Herholz K: A European multicentre PET study of fibrillar amyloid in Alzheimer's disease. Eur J Nucl Med Mol Imaging 2012;40:104-114.

-35 Ossenkoppele R, Tolboom N, Foster-Dingley JC, Adriaanse SF, Boellaard R, Yaqub M, Windhorst AD, Barkhof F, Lammertsma AA, Scheltens P, van der Flier WM, van Berckel BN: Longitudinal imaging of Alzheimer pathology using [11C]PIB, [18F]FDDNP and [18F]FDG PET. Eur J Nucl Med Mol Imaging 2012;39:990-1000.

-36 Li Y, Rinne JO, Mosconi L, Pirraglia E, Rusinek H, DeSanti S, Kemppainen N, Nagren K, Kim BC, Tsui W, de Leon MJ: Regional analysis of FDG and PIB-PET images in normal aging, mild cognitive impairment, and Alzheimer's disease. Eur J Nucl Med Mol Imaging 2008;35:2169-2181.

-37 Meyer PT, Hellwig S, Amtage F, Rottenburger C, Sahm U, Reuland P, Weber WA, Hull M: Dual-biomarker imaging of regional cerebral amyloid load and neuronal activity in dementia with PET and 11C-labeled Pittsburgh compound B. J Nucl Med 2011;52:393-400.

-38 Tolboom N, Yaqub M, van der Flier WM, Boellaard R, Luurtsema G, Windhorst AD, Barkhof F, Scheltens P, Lammertsma AA, van Berckel BN: Detection of Alzheimer pathology in vivo using both 11C-PIB and 18F-FDDNP PET. J Nucl Med 2009;50:191-197.

-39 Tolboom N, van der Flier WM, Boverhoff J, Yaqub M, Wattjes MP, Raijmakers PG, Barkhof F, Scheltens P, Herholz K, Lammertsma AA, Van Berckel BNM: Molecular imaging in the diagnosis of Alzheimer's disease: visual assessment of [11C]PIB and [18F]FDDNP PET images. J Neurol Psychiatry 2010;81:882-884.

40 Forsberg A, Engler H, Almkvist O, Blomquist G, Hagman G, Wall A, Ringheim A, Långström B, Nordberg A: PET imaging of amyloid deposition in patients with mild cognitive impairment. Neurobiol Aging 2008;29:14561465. 
Wahlster et al:: Clinical Assessment of Amyloid Imaging in Alzheimer's Disease:

A Systematic Review of the Literature

41 Furst AJ, Rabinovici GD, Rostomian AH, Steed T, Alkalay A, Racine C, Miller BL, Jagust WJ: Cognition, glucose metabolism and amyloid burden in Alzheimer's disease. Neurobiol Aging 2012;33:215-225.

-42 Grimmer T, Henriksen G, Wester HJ, Förstl H, Klunk WE, Mathis CA, Kurz A, Drzezga A: Clinical severity of Alzheimer's disease is associated with PIB uptake in PET. Neurobiol Aging 2009;30:1902-1909.

-43 Kadir A, Almkvist O, Forsberg A, Wall A, Engler H, Långström B, Nordberg A: Dynamic changes in PET amyloid and FDG imaging at different stages of Alzheimer's disease. Neurobiol Aging 2012;33:198.e1-198.e14.

-44 Fripp J, Bourgeat P, Acosta O, Raniga P, Modat M, Pike KE, Jones G, O'Keefe G, Masters CL, Ames D, Ellis KA, Maruff P, Currie J, Villemagne VL, Rowe CC, Salvado O, Ourselin S: Appearance modeling of 11C PIB PET images: characterizing amyloid deposition in Alzheimer's disease, mild cognitive impairment and healthy aging. Neuroimage 2008;43:430-439.

-45 Koivunen J, Scheinin N, Virta JR, Aalto S, Vahlberg T, Någren K, Helin S, Parkkola R, Viitanen M, Rinne JO: Amyloid PET imaging in patients with mild cognitive impairment: a 2-year follow-up study. Neurology 2011; 76:1085-1090.

-46 Lee JH, Kim SH, Kim GH, Seo SW, Park HK, Oh SJ, Kim JS, Cheong HK, Na DL: Identification of pure subcortical vascular dementia using 11C-Pittsburgh compound B. Neurology 2011;77:18-25.

47 Okello A, Koivunen J, Edison P, Archer HA, Turkheimer FE, Någren K, Bullock R, Walker Z, Kennedy A, Fox NC, Rossor MN, Rinne JO, Brooks DJ: Conversion of amyloid positive and negative MCI to AD over 3 years: an 11C-PIB PET study. Neurology 2009;73:754-760.

-48 Rabinovici GD, Rosen HJ, Alkalay A, Kornak J, Furst AJ, Agarwal N, Mormino EC, O’Neil JP, Janabi M, Karydas A, Growdon ME, Jang JY, Huang EJ, DeArmond SJ, Trojanowski JQ, Grinberg LT, Gorno-Tempini ML, Seeley WW, Miller BL, Jagust WJ: Amyloid vs FDG-PET in the differential diagnosis of AD and FTLD. Neurology 2011;77: 2034-2042.

49 Resnick SM, Sojkova J, Zhou Y, An Y, Ye W, Holt DP, Dannals RF, Mathis CA, Klunk WE, Ferrucci L, Kraut MA, Wong DF: Longitudinal cognitive decline is associated with fibrillar amyloid-beta measured by [11C]PIB. Neurology 2010;74:807-815.

50 Tolboom N, van der Flier WM, Yaqub M, Koene T, Boellaard R, Windhorst AD, Scheltens P, Lammertsma AA, Van Berckel BNM: Differential association of [11C]PIB and [18F]FDDNP binding with cognitive impairment. Neurology 2009;73:2079-2085.

51 Bennett DA, Schneider JA, Arvanitakis Z, Kelly JF, Aggarwal NT, Shah RC, Wilson RS: Neuropathology of older persons without cognitive impairment from two community-based studies. Neurology 2006;66:1837-1844.

52 Knopman DS, DeKosky ST, Cummings JL, Chui H, Corey-Bloom J, Relkin N, Small GW, Miller B, Stevens JC: Practice parameter: diagnosis of dementia (an evidence-based review). Report of the Quality Standards Subcommittee of the American Academy of Neurology. Neurology 2001;56:1143-1153.

53 Consensus report of the Working Group on: 'Molecular and Biochemical Markers of Alzheimer's Disease'. The Ronald and Nancy Reagan Research Institute of the Alzheimer's Association and the National Institute on Aging Working Group. Neurobiol Aging 1998;19:109-116.

54 McKhann GM, Knopman DS, Chertkow H, Hyman BT, Jack CR, Kawas CH, Klunk WE, Koroshetz WJ, Manly JJ, Mayeux R, Mohs RC, Morris JC, Rossor MN, Scheltens P, Carrillo MC, Thies B, Weintraub S, Phelps CH: The diagnosis of dementia due to Alzheimer's disease: recommendations from the National Institute on AgingAlzheimer's Association workgroups on diagnostic guidelines for Alzheimer's disease. Alzheimers Dement 2011;7:263-269.

55 Price JL, Morris JC: Tangles and plaques in nondemented aging and 'preclinical' Alzheimer's disease. Ann Neurol 1999;45:358-368.

56 Albert MS, DeKosky ST, Dickson D, Dubois B, Feldman HH, Fox NC, Gamst A, Holtzman DM, Jagust WJ, Petersen RC, Snyder PJ, Carrillo MC, Thies B, Phelps CH: The diagnosis of mild cognitive impairment due to Alzheimer's disease: recommendations from the National Institute on Aging-Alzheimer's Association workgroups on diagnostic guidelines for Alzheimer's disease. Alzheimers Dement 2011;7:270-279.

57 Rinne JO, Brooks DJ, Rossor MN, Fox NC, Bullock R, Klunk WE, Mathis CA, Blennow K, Barakos J, Okello AA, de Liano SRM, Liu E, Koller M, Gregg KM, Schenk D, Black R, Grundman M: 11C-PIB PET assessment of change in fibrillar amyloid- $\beta$ load in patients with Alzheimer's disease treated with bapineuzumab: a phase 2, doubleblind, placebo-controlled, ascending-dose study. Lancet Neurol 2010;9:363-372.

58 Davis V: Pfizer announces co-primary clinical endpoints not met in second phase 3 bapineuzumab study in mild-to-moderate Alzheimer's disease patients who do not carry the ApoE4 genotype. http://www.businesswire.com/news/home/20120806006130/en/Pfizer-Announces-Co-Primary-Clinical-Endpoints-MetPhase.

59 Phend C: Study: Hint of benefit for Alzheimer's drug. http://www.medpagetoday.com/Neurology/AlzheimersDisease/35218.

60 Morris JC: Cross sectional and longitudinal data from the Dominantly Inherited Alzheimer Network (DIAN) cohort. AD/PD 2013, Florence, March 6-10, 2013.

61 Schreiter NF, Brenner W, Nogami M, Buchert R, Huppertz A, Pape UF, Prasad V, Hamm B, Maurer MH: Cost comparison of 111In-DTPA-octreotide scintigraphy and 68Ga-DOTATOC PET/CT for staging enteropancreatic neuroendocrine tumours. Eur J Nucl Med Mol Imaging 2012;39:72-82.

62 Biasutti M, Dufour N, Ferroud C, Dab W, Temime L: Cost-effectiveness of magnetic resonance imaging with a new contrast agent for the early diagnosis of Alzheimer's disease. PLoS One 2012;7:e35559. 
-63 Rentz DM, Amariglio RE, Becker JA, Frey M, Olson LE, Frishe K, Carmasin J, Maye JE, Johnson KA, Sperling RA: Face-name associative memory performance is related to amyloid burden in normal elderly. Neuropsychologia 2011;49:2776-2783.

64 Brown BM, Peiffer JJ, Taddei K, Lui JK, Laws SM, Gupta VB, Taddei T, Ward VK, Rodrigues MA, Burnham S, Rainey-Smith SR, Villemagne VL, Bush A, Ellis KA, Masters CL, Ames D, Macaulay SL, Szoeke C, Rowe CC, Martins RN: Physical activity and amyloid- $\beta$ plasma and brain levels: results from the Australian Imaging, Biomarkers and Lifestyle Study of Ageing. Mol Psychiatry 2012, E-pub ahead of print.

65 Neumann PJ, Hammitt JK, Mueller C, Fillit HM, Hill J, Tetteh NA, Kosik KS: Public attitudes about genetic testing for Alzheimer's disease. Health Aff (Millwood) 2001;20:252-264.

66 Scheibler F, Zumbe P, Janssen I, Viebahn M, Schroer-Gunther M, Grosselfinger R, Hausner E, Sauerland S, Lange S: Randomized controlled trials on PET: a systematic review of topics, design, and quality. J Nucl Med 2012; 53:1016-1025.

67 Wolk DA, Zhang Z, Boudhar S, Clark CM, Pontecorvo MJ, Arnold SE: Amyloid imaging in Alzheimer's disease: comparison of florbetapir and Pittsburgh compound-B positron emission tomography. J Neurol Neurosurg Psychiatry 2012;83:923-926. 